\title{
Clinical and Epidemiological Characteristics of Cases Monitored by the Diagnosis of Kawasaki Disease
}

\author{
Kawasaki Hastalı̆ıı Tanısı ile Takip Edilen \\ Olgularımızın Klinik ve Epidemiyolojik Özellikleri
}

\author{
Ayşe Şahin', Lütfiye Şahin', Muhammed Karabulut'², Nazan Dalgıç' \\ ${ }^{1}$ Clinic of Pediatric Infectious Diseases, Sisli Hamidiye Etfal Training and Research Hospital, Istanbul, Turkey \\ ${ }^{2}$ Clinic of Pediatric Cardiology, Sisli Hamidiye Etfal Training and Research Hospital, Istanbul, Turkey
}

Cite this article as: Şahin A, Şahin L, Karabulut M, Dalgı̧ N. Clinical and epidemiological characteristics of cases monitored by the diagnosis of kawasaki disease. | Pediatr Inf 2018;12(3):e87-e92

\begin{abstract}
Objective: Kawasaki disease (KD) is an acute systemic vasculitis which is more common in children between 6 months and 5 years of age. The aim of this study was to evaluate the epidemiological and clinical features of patients diagnosed with KD and treated in our Pediatric Infection Disease Clinic for the past decade.
\end{abstract}

Material and Methods: Forty-one cases with the diagnosis of KD from the retrospective file records were evaluated in terms of epidemiological, clinical, laboratory, treatment and complications at Şişli Hamidiye Etfal Pediatric Infection Clinic between $1^{\text {st }}$ January 2008 and $31^{\text {st }}$ December 2017. Four out of five semptoms resulting from at least five days of fever with rash, extremity changes, intra-oral mucosa and lip involvement, non-purulent conjunctivitis and cervical lymphadenopathy were diagnosed as classic Kawasaki. Intravenous immunoglobulin (IVIG) and acetylsalicylic acid treatment were administered to all patients upon diagnosis.

Results: 41 patients were included in the study, the mean age was 29.2 \pm 20.7 months (2-76 months), 24 (58.5\%) were male and 17 (41.5\%) were female. $87.8 \%$ of the patients were under the age of five and $43.9 \%$ were under two years of age. Diagnosis acquisition time was $8.2 \pm 2.8$ (5-16 days) days. Most patients were diagnosed in spring and winter. The most common findings were nonpurified conjunctivitis (97.6\%) and oral mucosa and lip change (92.7\%). 24 (58.5\%) patients were diagnosed as complete KD. $17(41.5 \%)$ patients were evaluated as incomplete KD. Coronary artery involvement was detected in 25 (60.9\%) patients, three patients had mitral regurgitation (MR) accompanied by coronary
Öz

Giriş: Kawasaki hastalığı (KH) 6 ay-5 yaş arası çocuklarda daha sık görülen, etyolojisi tam olarak bilinmeyen, akut sistemik bir vaskülittir. Bu çalışmada son on yılda hastanemiz Çocuk Enfeksiyon Kliniğinde KH tanısı alan ve tedavi edilen olguların epidemiyolojik ve klinik özelliklerinin değerlendirilmesi amaçlanmıştır.

Gereç ve Yöntemler: Bu çalışmada 1 Ocak 2008 ila 31 Aralık 2017 tarihleri arasında Şişli Hamidiye Etfal Çocuk Enfeksiyon Kliniğinde KH tanısı ile izlenen 41 olgu geriye dönük dosya kayıtlarından epidemiyolojik, klinik, laboratuvar, tedavi ve komplikasyonlar açısından değerlendirildi. En az 5 gün süren ateş ile beraber döküntü, ekstremite değişiklikleri, ağız içi mukozası ve dudak tutulumu, pürülan olmayan konjunktivit ve servikal lenfadenopatiden oluşan beş bulgudan dört tanesinin olması durumunda klasik Kawasaki tanısı konuldu. Tanı anında tüm hastalara intravenöz immünglobulin (IVIG) ve asetil salisilik asit tedavisi uygulandı.

Bulgular: Çalışmaya 41 hasta dahil edildi, yaş ortalaması $29.2 \pm 20.7$ ay (2-76 ay), 24 (\%58.5)'ü erkek, 17 (\%41.5)'si kızdı. Hastaların \%87.8'i beş yaş altında, \%43.9'u iki yaş altındaydı. Tanı alma süresi $8.8 \pm 2.9$ (5-16 gün) gündü. En fazla hasta ilkbahar ve kış mevsiminde tanı almıştı. En sık saptanan bulgu nonpürülan konjunktivit (\%97.6) ile oral mukoza ve dudak değişikliğiydi (\%92.7). Komplet KH olarak 24 (\%58.5) hasta tanı aldı. On yedi (\%41.5) hasta ise inkomplet KH olarak değerlendirildi. Koroner arter tutlumu 25 (\%60.9) hastada saptandı, üç hastada mitral yetmezlik (MY) koroner tutuluma eşlik ediyordu, iki hastada ise MY ve perikardiyal efüzyon tespit edildi. İlk doz IVIG tedavisine yanıtsız 4 (\%9.8) hastaya ikinci doz IVIG tedavisi uygulandı. 
involvement, while MR and pericardial effusion were detected in two patients. A second dose of IVIG treatment was administered to $4(9.8 \%)$ patients who did not respond to a first dose of IVIG treatment.

Conclusion: Kawasaki disease is a clinically defined systemic vasculitis of mainly medium-sized arteries. Due to incomplete cases that do not fully meet the diagnostic criteria, all criteria should not be expected to be met in the diagnosis of KD for a case of fever lasting more than 5 days. While there may be serious complications in cases of delay in diagnosis and in cases of non-responsiveness to treatment, a good prognosis is usually obtained with early diagnosis and correct treatment.

Keywords: Kawasaki disease, vasculitis, coronary artery, fever

\section{Introduction}

Kawasaki Disease (KD) is an acute, self-limited pyretic systemic vasculitis of childhood. Main findings are fever, conjunctivitis, skin and mucous membrane involvement and cervical lymphadenopathy. It is a disease causing significant mortality and morbidity, invading many mid-sized arteries, mainly coronary artery. If not treated, it results in coronary artery disease up to $25 \%$. Therefore, early diagnosis and treatment should be done in a timely and appropriate manner. It is reported that it is the most common cause of acquired heart disease in developed countries. In Japan in 1967, the disease was first defined by $\mathrm{Dr}$. Tomisaku Kawasaki in 50 cases (1-3). Its etiology is still not fully understood despite the half a century, it is thought that genetic factors may have a role in the etiology due to fact that the individuals with high incidence living in the low incidence region cause an increase in the frequency of the disease and the incidence of the disease is higher in siblings. In recent years, significant relationships have been observed with KD in the FAM167A-BLK region of the 8p23-p22 chromosome (1). It is stated that an agent that stimulates the immune system in the genetically sensitive host may be involved in the etiology.
Sonuç: Kawasaki hastalığı, esas olarak orta büyüklükteki arterlerin klinik olarak tanımlanan sistemik bir vaskülitidir. Tanı kriterlerini tam sağlamayan inkomplet olgular nedeniyle odağı tespit edilemeyen 5 günden uzun süren ateş durumunda tüm kriterlerin sağlanması beklenmemeli ve $\mathrm{KH}$ tanısında düşünülmelidir. Tanıda gecikme ve tedaviye yanıtsız olgularda ciddi komplikasyonlar olabilirken, erken tanı ve doğru tedavi ile genellikle iyi bir prognoza sahiptir.

Anahtar Terimler: Kawasaki hastalığı, vaskülit, koroner arter, ateş

It is seen in all races and ethnic origins, but is more common in Asia, especially in Japanese. In recent studies, the average incidence in Japan for children under 4 years of age was reported to be $240 / 100.000$ and in North America 17/100.000 (4). Although there is no clear data from our country, it is reported that it is $9 \%$ of all cases of vasculitis and it is reported to be the second most common after Henoch Schönlein Vasculitis (5). It is reported that $85 \%$ of the patients are under 5 years of age and are more common in males.

A specific laboratory test or a lack of clinical signs and symptoms for the definitive diagnosis of KD causes difficulties in diagnosis. The presence of four of the 5 main findings in addition to a five-day or long-lasting fever makes the diagnosis of $\mathrm{CH}$ (Table 1). Some algorithms were tried to be developed in cases where the diagnostic criteria could not be achieved. McCrindle et al. developed algorithm; In the presence of 2 or 3 clinical criteria in addition to a fever lasting for at least 5 days, and if there are 3 or more supporting laboratory findings, it is defined as incomplete KD. If the laboratory findings are less than three, echocardiography (ECO) is a criterion of positive finding and an incomplete diagnosis of KD and treatment is recommended (Table 1) (6).

Table 1. Classic diagnostic criteria for Kawasaki disease $(3,6)$

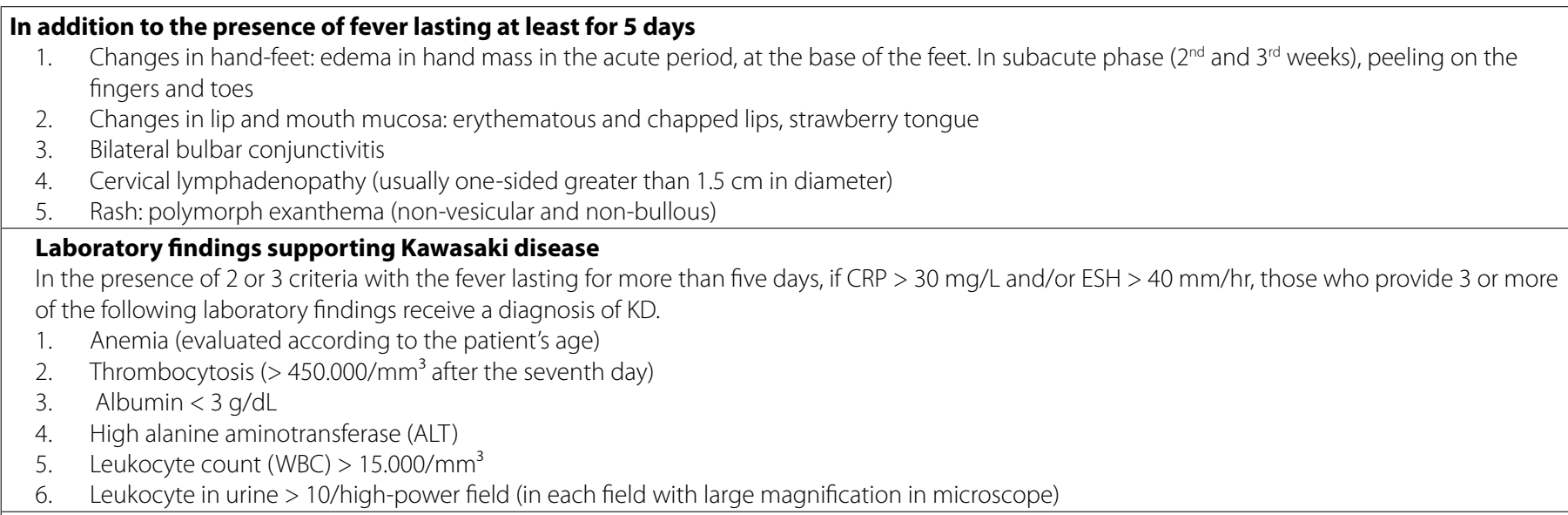


In this study, demographic structure, clinical and laboratory findings, treatment and follow-up results of 41 patients who were followed-up and treated with the diagnosis of KD in the last 10 years were evaluated retrospectively.

\section{Materials and Methods}

The study included 41 patients who were diagnosed with KD and were treated between January 1, 2008 and December 31, 2017 in our Pediatric Infectious Disease Clinic. Demographic structure, epidemiological characteristics, clinical status, laboratory findings, treatment and complications of the patients were recorded from retroactive files. The KD diagnosis was made according to the diagnostic criteria of the American Heart Academy $(6,7)$. Patients who fulfilled four of the five diagnostic criteria in addition to fever lasting more than five days were defined as complete CD (Table 1). Those who had less than four clinical criteria and who met at least 3 of the supporting laboratory findings or who had coronary artery involvement were evaluated as incomplete KD. Laboratory findings; complete blood count, erythrocyte sedimentation rate (ESR), C-reactive protein (CRP), aspartate aminotransferase (AST), alanine aminotransferase (ALT), gamma glutamyl transferase (GGT), serum albumin, sodium ( $\mathrm{Na})$ and complete urine analysis were recorded.

Transthoracic ECO was performed by the pediatric cardiologist in all patients. Coronary artery diameters were evaluated in the parasternal short axis window. According to the $Z$ score adapted to the patient's height and weight, If $Z$ score is $<2$, there is no involvement, only dilatation between 2 and 2.5 , small aneurysm between 2.5 and 5 , and if $Z$ score is between 5 and 10 (coronary artery diameter $<8 \mathrm{~mm}$ ), it was considered as middle aneurysm, If the $Z$ score $>10$ absolute size is $>8 \mathrm{~mm}$ and above, it is considered as large and giant aneurysm. In addition, the presence of coronary artery diameter more than 1.5 times of the adjacent segment was also evaluated in favor of the involvement $(6,7)$. Intravenous immunoglobulin (IVIG) was administered at $2 \mathrm{~g} / \mathrm{kg}$ infusion for 12 hours and acetyl salicylic acid (ASA) was administarted at a dose of $80 \mathrm{mg} / \mathrm{kg} /$ day. In 4872 hours, in crease in fever was evaluated as clinical response. The dose of ASA was decreased to the dose of $3-5 \mathrm{mg} / \mathrm{kg} / \mathrm{day}$ which is antiagregan dose according to clinical and laboratory results. The duration of treatment was regulated according to coronary artery involvement in control ECO. ASA therapy was discontinued in patients with normal control echocardiography. Patients whose fever did not fall within 48-72 hours despite IVIG and ASA treatment were accepted as unanswered and $2^{\text {nd }}$ dose IVIG was administered.

\section{Statistical Analysis}

SPSS 15.0 for Windows program was used for statistical analysis. The descriptive statistics were considered as number and percentage for categorical variables, mean, standard deviation, and minimum, maximum, median for numerical variables. The independent two group comparisons of the numerical variable were performed with the Mann-Whitney $\mathrm{U}$ test when the normal distribution condition was provided by Student's t-test and the normal distribution condition was not provided. The ratios of categorical variables between groups were compared with the Chi-square analysis. Statistical alpha significance level was accepted as $p<0.05$.

\section{Results}

Of the 41 patients included in the study, 24 (58.5\%) were male and $17(41.5 \%)$ were female and the male/female ratio was 1.41. The mean age of the patients was 29.2 months (2-76 months) at the time of diagnosis, $87.8 \%$ under the age of five, and $43.9 \%$ under two years of age. The mean time from onset of fever to diagnosis was $8.8 \pm 2.9$ (5-16 days). The duration of hospitalization was $8.8 \pm 3.5$ (3-17 days). $82.9 \%(n=34)$ of the patients were diagnosed in the first 10 days, acute phase. Considering the seasonal distribution, the highest number of patients who applied was in spring (39\%) and winter (11\%) months (Figure 1). From 2008 onwards, there was a statistically significant $(p=0.001)$ increase in the incidence of incomplete diagnosis of KD as the year of diagnosis progressed. The most common finding in addition to five-day or more fever was non-purified conjunctivitis ( $n=40,97.6 \%)$ and intra-oral and lip changes $(\mathrm{n}=38,92.7 \%)$ (Table 2).

Table 2. Demographic and clinical findings of Kawasaki patients

\begin{tabular}{|l|c|}
\hline & n (\%) \\
\hline Patient with Kawasaki & $41(100)$ \\
\hline Age (months) & \\
\hline$<2$ years & $18(43.9)$ \\
\hline $2-5$ years & $18(43.9)$ \\
\hline$>5$ years old & $5(12.2)$ \\
\hline Gender & \\
\hline Male & $24(58.5)$ \\
\hline Female & $17(41.5)$ \\
\hline Clinical findings (diagnosis criteria) & \\
\hline Fever & $41(100)$ \\
\hline Conjunctivitis & $40(97.6)$ \\
\hline Oral and lip change & $38(92.7)$ \\
\hline Lymphadenopathy & $35(85.4)$ \\
\hline Rash & $24(58.5)$ \\
\hline Hand-foot change & $21(51.2)$ \\
\hline Other clinical findings & \\
\hline Sterile pyuria & $3(7.3)$ \\
\hline Aseptic meningitis & $2(4.9)$ \\
\hline Gall bladder hydropsu & $1(2.4)$ \\
\hline Enlargening in BCG scar & $1(2.4)$ \\
\hline BCG: Bacille Calmette Guerin. & \\
\hline
\end{tabular}




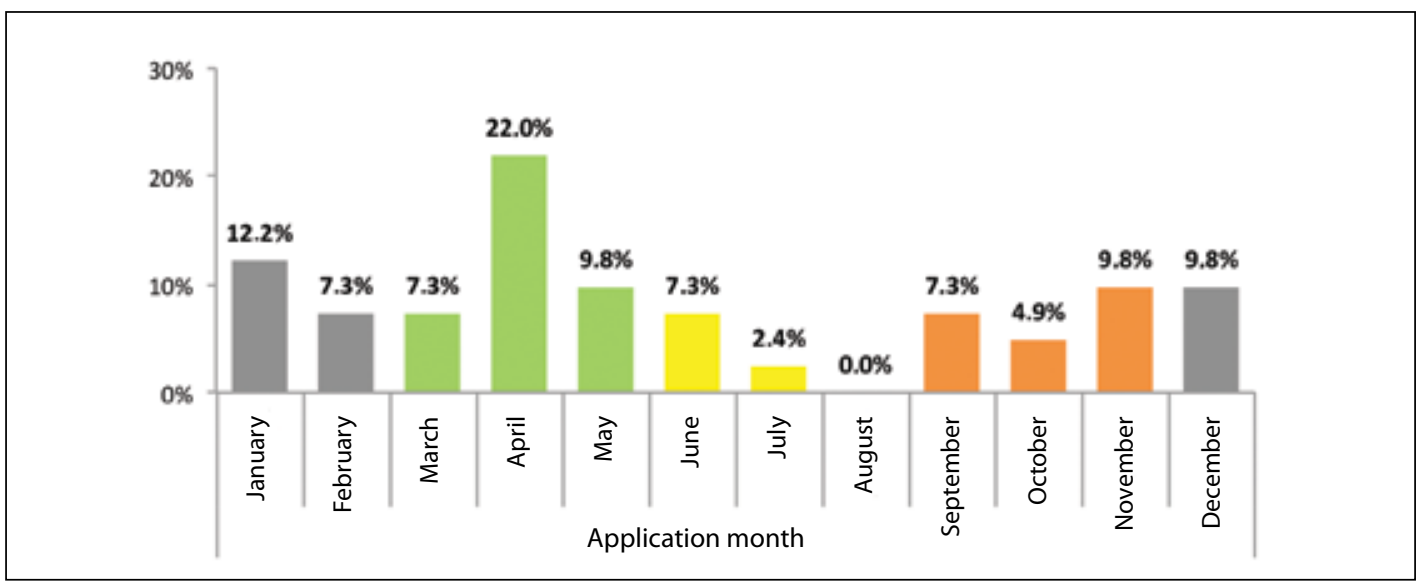

Figure 1. Distribution of Kawasaki patients by months and seasons at the time of admission.

Table 3. Echocardiography (ECO) findings

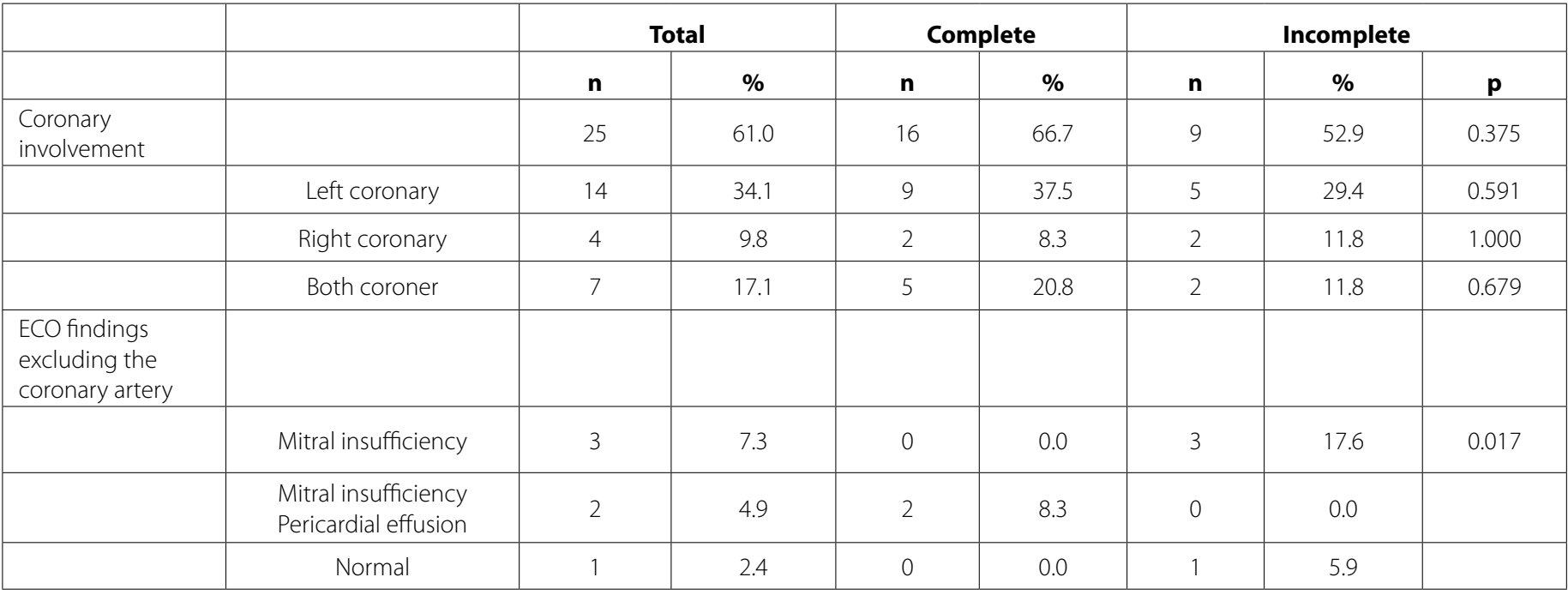

Other clinical findings not included in the clinical diagnostic criteria; sterile pyuria was detected in three $(7.3 \%)$ cases, aseptic meningitis was detected in two (4.9\%) cases, reactivation was detected in one (2.4\%) case at the BCG graft site. 24 $(58.5 \%)$ patients who met the diagnostic criteria were diagnosed as complete KD. 17 (41.4\%) patients were evaluated as incomplete KD with clinical and laboratory findings.

The first ECHO findings were normal in $48.8 \%(n=20)$ of our patients. A total of 25 (60.9\%) patients had coronary involvement during follow-up. Coronary artery involvement was detected in 9 (52.9\%) of the patients with incomplete KD, and in $16(66.6 \%)$ of the patients with complete KD. The most common finding which was coronary artery ectasia was seen in 11 (28.6\%) patients in the left coronary artery and in 6 patients in both coronaries (14.6\%). In addition to coronary involvement, 3 (7.3\%) patients had mitral insufficiency, 2 patients had mitral insufficiency and accompanying pericardial effusion (Table 3).

\section{Discussion}

In addition to fever lasting more than five days for the diagnosis of KD, four of the five main diagnostic criteria are sufficient. However, there are difficulties in diagnosis in the presence of less than four (two or three) signs with fever. In this case, evaluation of patients with supportive laboratory findings and ECO imaging increases the likelihood of diagnosis. In recent epidemiological studies from Japan, the incidence of incomplete KD has been reported to be $19.8 \%$ (8). In the studies conducted in our country, rates between $13.6 \%$ and $42 \%$ have been reported $(9,10)$. In our study, this rate was found to be $41.5 \%$. In our study, 
it was observed that in the last 10 years, there was a significant increase $(p=0.001)$ in the diagnosis of incomplete KD, and to diagnose and start treatment for the $82.9 \%$ of our patient within 10-day acute period have shown us that the DK is more thought in the differential diagnosis of the non-faller fever in terms of the previous years. In all of our cases, CRP and sedimentation levels were high in supportive laboratory findings (Table 4). Thrombocytosis, an important finding of the subacute period, was diagnosed in 15 (36.6\%) patients, diagnosed and treated for 10 days or more. One week after the diagnosis, 23 (56\%) patients had an average platelet count of $512.390 \pm 215.186$. This was consistent with other studies.

$\mathrm{KD}$ is more common in infants and children and males (6). In our study, $87.8 \%$ of the patients were under the age of 5 , $43 \%$ were under the age of 9 , and $58.5 \%$ of the patients were male. This was consistent with the literature (M/F was 1.41). Being a male patient over 6 months and 9 years of age, having a Asia and Pacific island and Hispanic ethnicity are an indicator of poor prognosis. The presence of neutrophils, elevation of thrombocytopenia, hyponatremia, CRP and increase in transaminases are helpful to poor response to $\mathrm{t} I \mathrm{VIG}$ and/or coronary artery lesion is helpful to poor prognosis (11). Three (7.3\%) of our patients were under 6 months and all had coronary artery involvement. One patient had an aneurysm in both coronary arteries and the aneurysm continued during 1 year follow-up.

There many studies investigaitng the KD in the basis of season. In an epidemiological study from Japan in 2018, a sharp peak was observed in all age groups, most commonly in winter (12). In a study conducted in South Korea in recent years, especially in summer: June and July, in winter: December and January were reported to be the most common (13). In the United States, the frequency is reported in winter and spring months (4). In many studies from our country, there are more frequent case reports in winter and spring months. In our study, patients were most frequently diagnosed in spring and winter (14-17). The seasonal variation of the disease suggests that an

Table 4. Laboratory findings

\begin{tabular}{|l|c|}
\hline & Total \\
\hline Diagnosis instant & Average \pm SD \\
\hline Hemoglobin $(\mathrm{g} / \mathrm{dL})$ & $10.5 \pm 1.2$ \\
\hline White blood cell $\left(\mathrm{mm}^{3}\right)$ & $18311.2 \pm 7602.6$ \\
\hline Platelet $\left(\mathrm{mm}^{3}\right)$ & $420195.1 \pm 214366.1$ \\
\hline Sodium & $134.6 \pm 2.9$ \\
\hline CRP $(\mathrm{mg} / \mathrm{dL})$ & $112.6 \pm 90.6$ \\
\hline ESH $(\mathrm{mm} / \mathrm{h})$ & $89.4 \pm 32.5$ \\
\hline AST & $36.5 \pm 20.2$ \\
\hline ALT & $38.6 \pm 49.7$ \\
\hline AST: Aspartate aminotransferase, ALT: Alanine aminotransferase, \\
CRP: C-reactive protein, ESR: Erythrocyte sedimentation rate.
\end{tabular}

infectious agent may play a role, although it is not fully proven in the etiology.

The most common diagnostic criteria in our patients was nonpulping conjunctivitis and changes in the intraoral and lip changes $(18,19)$. Ad this was in compliance with many studies. In addition to classical diagnostic criteria, it can be seen in other clinical findings, important for the diagnosis. In our cases, there were aseptic meningitis, sterile pyuria, gallbladder hydrops and Bacille Calmette-Guerin (BCG) inoculum site reactivation (redness, crusting). In the BCG vaccine scar, erythema was first reported by Dr. Tomisaku Kawasaki. In the literature, there are publications reporting that it is common in $30-50 \%$ of patients, it is emphasized that there may be a specific clinical finding that can be helpful in incomplete cases especially in the early diagnosis because it is not included in the diagnostic findings but it is the finding of the acute period (20). Case reports from our country and a case in a study with 12 cases (16.7\%) were reported $(21,22)$. In our patient group, one $(2.4 \%)$ patient had BCG vaccine reactivation. In our country, this finding of $B C G$ vaccine present in routine childhood vaccination scheme is valuable for diagnosis.

Coronary involvement in our country has been reported between $13 \%$ and $56.4 \%$ (10.17). In the literature, it is reported as $25 \%$. In our study, $60.9 \%$ of the patients had coronary involvement. In the literature, it is reported that the incidence of coronary artery involvement is high in the incomplete KD. Although there was no statistically significant difference in our series, coronary artery involvement was higher in patients with complete $\mathrm{KD}$ compared to incomplete $\mathrm{CD}$. This may be explained by the evaluation of patients by different pediatric cardiologists over a ten-year period. Although the rate of coronary artery involvement in our study was parallel to similar studies in our country, it was more common than the literature. The high incidence of coronary artery involvement in our patients can be explained by the late admission of our patients because we are a reference hospital at the third level.

The main treatment of KD is IVIG and aspirin, especially if it is given in the first 10 days, they are more effective. The rate of development of coronary artery disease is reduced to $3-5 \%$ in the treated patients and up to $25 \%$ in untreated patients $(6,7)$. Corticosteroids can be used effectively in cases resistant to IVIG treatment (23). In our study, IVIG and high dose aspirin treatment was given to all cases at the time of diagnosis. Four patients required second dose of IVIG treatment, and no patients were required to use corticosteroids.

\section{Conclusion}

Kawasaki disease is a clinically defined systemic vasculitis of mainly medium-sized arteries. KD should be considered in case of a fever lasting more than 5 days, with no focus due 
to incomplete cases that do not fully meet the diagnostic criteria. While there may be serious complications in cases with delay in diagnosis and in cases not responding to treatment, they usually have a good prognosis with early diagnosis and correct treatment.

Ethics Committe Approval: Ethics committee aproval was not received due to the retrospective nature of this study.

Peer-review: Externally peer-reviewed.

Author Contributions: Concept - AŞ; Desing - AŞ; Data Collection and/or Processing - AŞ, LŞ, ND, MK; Analysis and Writing - AŞ, ND, Literature Review - AŞ; Critical Review - AŞ, ND.

Conflict of Interest: The authors have not reported a conflict of interest.

Financial Disclosure: There is no financial support in this study.

\section{References}

1. Greco A, De Virgilio A, Rizzo MI, Tombolini M, Gallo A, Fusconi M, et al. Kawasaki disease: an evolving paradigm. Autoimmun Rev 2015;14:7039.

2. Bayers S, Shulman ST, Paller AS. Kawasaki disease Part II. Complications and treatment. J Am Acad Dermatol 2013;69: 513e.1-8.

3. Sanchez-Manubens J, Bou R, Anton J. Diagnosis and classification of Kawasaki disease. J Autoimmun 2014;48-49:113-7.

4. Hedrich CM, Schnabel A, Hospach. Kawasaki disease. Front Pediatr 2018;6:198.

5. Ozen S, Bakkaloglu A, Dusunsel R, Soylemezoglu O, Ozaltin F, Poyrazoglu $\mathrm{H}$, et al. Childhood vasculitis in Turkey: a nationwide survey. Clin Rheumatol 2007;26:196-200.

6. McCrindle BW, Rowley AH, Newburger JW, Burns JC, Bolger AF, Gewitz $M$, et al. Diagnosis, treatment, and long-term management of Kawasaki disease: a scientic statement for health professionals from the American heart association. Circulation 2017;135:e927-99.

7. Newburger JW, Takahashi M, Gerber MA, Gewitz MH, Tani LY, Burns JC, et al. Diagnosis, treatment, and long-term management of Kawasaki disease: a statement for health professionals from the Committee on Rheumatic Fever, Endocarditis, and Kawasaki Disease, Council on Cardiovascular Disease in Young, American Heart Association. Pediatrics 2004; 114:1708-33.

8. Makino N, Nakamura Y, Yashiro M, Ae R, Tsuboi S, Aoyama Y, et al. Descriptive epidemiology of, Kawasaki disease in Japan, 20112012: from the results of the 22nd nationwidw survey. J Epidemiol 2015;25:239-45.
9. Bozlu G, Tezol Ö, Karpuz D, Hallıoğlu O, Kuyucu N. Kawasaki hastalığı: Akut atakla hastaneye getirilen 44 çocuğun klinik ve kardiyolojik erken dönem özellikleri ve prognozları. Türkiye Klinikleri J Pediatr 2015;24:138-42.

10. Bozabalı S. Kawasaki hastalığı: Olgularımızın klinik ve epidemiyolojik özellikleri. Türkiye Çocuk Hastalıkları Dergisi 2018; DOI: 10.12956/ tjpd.2018.329.

11. Son MBF, Newburger JW. Kawasaki disease. Pediatr Rev 2018;39:78-90.

12. Ozeki Yukie, Yamada F, Saito A, Kishimoto T, Yashiro M, Makino N, et al. Epidemiologic features of Kawasaki disease distinguised by seasonal variation: an age-specific analysis. Ann Epidemiol 2018;28:796-800.

13. Kim GB, Han JW, Park YW, Song MS, Hong YM, et al. Epidemiologic features of Kawasaki disease in South Korea: data from nationwidw syrvey, 2009-2011. Pediatr Infect Dis J 2014;33:24-7.

14. Arat $C$, Acar Y, Türkmenoğlu Y, Sayar $T$, Hamilçıkan SB, Sazak S, et al. Kawasaki hastalığı: 21 olgunun değerlendirilmesi. Cukurova Med J 2016;41:97-104.

15. Topçu S, Doğan ÖA, Öz N, Tanır G. Clinical evaluation of 49 cases with Kawasaki Disease: Aretrospective cohort study. J Pediatr Inf 2014;8:6470.

16. Binnetoğlu K, Kuşdal Y, Altun G, Babaoğlu K. Kocaeli bölgesinde Kawasaki hastalığı tanısı alan 24 hastanın klinik ve epidemiyolojik özellikleri. Çocuk Enf Derg 2010;4:71-5.

17. Gülhan B, Kesici S, Beken S, Çilsal E, Kale G. Varying clinical features of Turkish Kawasaki disease patients. Turk J Pediatr 2012;54:1-6.

18. Gündüz $M$, Akın Y, Kuzaytepe EC, Karaaslan A, Polatoğku EC, Kıyak H. Clinical evaluation of children with Kawasaki Disease hospitalized in our clinic: a retrospective study. South Clin Ist Euras 2017;28:255-60.

19. Özyürek AR, Ülger Zülal, Ertürk L, Gürses D. Kawsaki hastalığı: 11 vakanın değerlendirilmesi. Çocuk Sağlığı ve Hastalıkları Dergisi 2004;47:167-71.

20. Rezai MS, Shahmohammadi S. Erythema at BCG inoculation site in Kawasaki diseas patients. Mater Socionmed 2014;26:256-60.

21. Kara A, Asal GT, Tezer H, Devrim I, Cengiz AB, Yurdakök K, et al. Kawasaki hastalığı ve BCG reaktivasyonu: Bir vaka takdimi. Çocuk Sağlığı ve Hastalıkları Dergisi 2006;49:42-5.

22. Kara SS, GüllüUU, Balaban I. Kawasaki hastalığı: Erzurum ilinde izlenen çocuk hastaların değerlendirilmesi. Izmir Dr. Behçet Uz Çocuk Hast Dergisi 2017;7:113-20.

23. Chen S, Dong Y, Kiuchi MG, Wang J, Li R, Ling Z, et al. Coronary artery complication in Kawasaki disease and the importance of early intervention: A systematic review and meta-analysis. JAMA Pediatr 2016;170:1156-63. 